NBER WORKING PAPER SERIES

\title{
MARIJUANA DECRIMINALIZATION: WHAT DOES IT MEAN IN THE UNITED STATES?
}

\author{
Rosalie Liccardo Pacula \\ Jamie F. Chriqui \\ Joanna King \\ Working Paper 9690 \\ http://www.nber.org/papers/w9690
NATIONAL BUREAU OF ECONOMIC RESEARCH
1050 Massachusetts Avenue
Cambridge, MA 02138 \\ May 2003
}

\begin{abstract}
Research presented in this paper was supported by a grant from the National Institute on Drug Abuse (R01DA12724) to RAND. Additional support for analysis time of Dr. Chriqui and Ms. King was provided by the ImpacTeen Project, A Robert Wood Johnson Foundation Initiative. The opinions expressed in this paper are those of the authors and do not reflect the opinions of the authors' institutions or funding agencies. We gratefully acknowledge research assistance from Karen Ross, who spent considerable effort preparing the NELS data for analysis. We also gratefully acknowledge helpful comments from Frank Chaloupka, Jon Caulkins, Mark Kleiman, Peter Reuter, and Gary Zarkin on an earlier draft of this paper. The views expressed herein are those of the authors and not necessarily those of the National Bureau of Economic Research.
\end{abstract}

(C2003 by Rosalie Liccardo Pacula, Jamie F. Chriqui, and Joanna King. All rights reserved. Short sections of text not to exceed two paragraphs, may be quoted without explicit permission provided that full credit including Cnotice, is given to the source. 
Marijuana Decriminalization: What does it mean in the United States?

Rosalie Licardo Pacula, Jamie F. Chriqui, and Joanna King

NBER Working Paper No. 9690

May 2003

JEL No. I1, K4

\section{$\underline{\text { ABSTRACT }}$}

It is well known in the drug policy field that eleven states reduced the criminal sanctions associated with possession of small amounts of marijuana. In this paper we review the eleven original decriminalization statutes, documenting key dimensions of these laws and identifying their common denominator. We then examine state laws in effect as of December 31, 1999, along the same key dimensions and show that it is impossible to uniquely identify the so-called decriminalized states. We show the extent to which non-decriminalized states have also reduced penalties associated with possession of small amounts of marijuana as early as 1989, calling into question the interpretation of studies evaluating this policy during the past decade. We conclude by showing that the inclusion of legal dimensions of the policy does not diminish the association identified between decriminalization and recent use, raising questions about how researchers should interpret such findings.

Rosalie Liccardo Pacula

RAND

1700 Main Street

PO Box 2138

Santa Monica, CA 90407-2138

and NBER

pacula@rand.org

Joanna King

The Maya Tech Corporation

1100 Wayne Avenue, Suite 900

Silver Spring, MD 20910

jking@mayatech.com
Jamie F. Chriqui

The MayaTech Corporation

1100 Wayne Avenue, Suite 900

Silver Spring, MD 20910

jchriqui@mayatech.com 
A growing amount of attention has been given to the recent rise in marijuana arrests in the popular press, with many articles mentioning that this increase in arrest rates has occurred despite stable use rates. Critics of the federal government's current marijuana policy interpret the arrest and use trends as evidence of a crack-down by law enforcement against non-violent drug offenders (Thomas, 1998; Gettman, 2000a). They argue that this policy position has placed an unnecessary burden on the criminal justice system and introduced otherwise law-abiding citizens to the criminal justice system. Advocates argue in favor of a change in the legal status of marijuana, suggesting that legalization would save the criminal justice system while minimally affecting demand. Claims regarding the impact of legalization on demand are based on evidence from selected studies examining the effects of marijuana decriminalization on marijuana use.

The empirical evidence examining the effect of decriminalization policy on use rates in the United States is actually quite mixed. A number of studies conducted shortly after the laws took effect in the 1970s found either no change in marijuana use or an increase that was slight and temporary (Single, 1989; Maloff, 1981; Johnston, O’Malley and Bachman, 1981). Subsequent studies relying on cross-state variation in decriminalization status using more recent data from the 1980s and 1990s had mixed results, with some studies showing no effect (Pacula, 1998; Thies and Register, 1993; DiNardo \& Lemieux, 1992) and other studies showing a positive and statistically significant effect (Saffer and Chaloupka, 1999; Chaloupka et al, 1999;

Chaloupka, Grossman and Tauras, 1999; Model, 1993). Although several hypotheses have been offered for the inconsistency in findings, little empirical work has been done trying to explore this issue. 
It is widely recognized in the drug policy field that eleven states enacted legislation during the 1970s that reduced the criminal sanctions associated with possession of small amounts of marijuana. In 1973, Oregon was the first to lower its penalties for marijuana. It was followed by Colorado, Alaska, and Ohio in 1975; California, Maine and Minnesota in 1976; Mississippi, New York and North Carolina in 1977; and Nebraska in 1978 (MacCoun and Reuter, 2001). ${ }^{1}$ These eleven states, with the addition of Arizona in 1996, have commonly been referred to in the literature and policy debate as "decriminalized" states and are the states that are commonly grouped together in empirical analyses. For ease of exposition, we too will refer to these states as "decriminalized states." Despite a common label, little work has been done documenting the elements of these laws that actually differentiate them from the remaining state laws.

In this paper we review the eleven original decriminalization statutes from the 1970s, documenting key dimensions of these laws and identifying the common denominator across each of these. We then examine state laws in effect as of December 31, 1999, along the same key dimensions identified in the eleven original decriminalization statutes and show that it is impossible to uniquely identify the so-called decriminalized states using the common denominator of the statutes enacted during the 1970s. We show the extent to which nondecriminalized states have also reduced penalties associated with possession of small amounts of marijuana and show that many of these lower penalties existed as early as 1989 , calling into question the interpretation of studies evaluating the effects of decriminalization using data from the past decade. We then reconsider the association between decriminalization and use rates by examining how this association changes with the inclusion of particular legal dimensions of the

\footnotetext{
${ }^{1}$ South Dakota also enacted a decriminalization provision in 1977, but it was immediately repealed. Only two states have changed their status since these original laws were passed. In 1990, Alaska modified its statute and recriminalized possession of marijuana. In 1996, Arizona decriminalized possession of small amounts of marijuana.
} 
policy using a nationally representative sample of high school students from the 1990 National Educational Longitudinal Survey (NELS).

\section{The Data}

The information on state marijuana laws presented in this paper represents original legislative data collected from state statutes by lawyers and policy analysts at The MayaTech Corporation. State-level penalty information for first offence marijuana possession offences was collected for all states from 1989 through $1999 .^{2}$ In addition, historical statutes for the eleven states that decriminalized during the 1970 s were also collected and evaluated. Penalties that were captured included the minimum and maximum jail term, minimum and maximum fine, conditional discharge provisions, diversion provisions, and expungement provisions for the lowest two quantity trigger amounts. States differ in the level of penalty applied based on the quantity of marijuana an offender is caught possessing. For ease of comparison, we focus our analyses in this paper on penalties applying to the lowest quantity amount specified in these laws, typically specified as "any" amount. Certain states impose harsher penalties for possession violations involving larger quantities, represented through higher trigger amounts (e.g. amounts greater than one ounce). ${ }^{3}$

State statutes on laws in effect as of December 31 st of each year were obtained from Westlaw and hard copies of state statutory compilations. For each state and year, a legislative analyst reviewed and coded the provisions of the law using an analytic form designed to capture consistent data across the states. The coding sheets and laws were then reviewed by an attorney to validate and correct the coding, as necessary. In the case of the eleven original

\footnotetext{
2 Throughout this paper, we use the term "state" to refer to the 50 states and the District of Columbia. In all but a few specified cases, the data presented herein pertain to first-time marijuana possession offenses.

${ }^{3}$ For more information on the specific penalties associated with possession of higher quantities, see Illicit Drug Policies: Selected Laws from the 50 States (Chriqui et al., 2002).
} 
decriminalization statutes from the 1970s, an attorney examined each trying to identify common elements applied in all eleven states using the same analytic form, although examining many of the elements in greater detail.

Our conditional discharge/diversion variable reflects instances where compliance with the specified conditions leads to a dismissal of charges. For instance, if a state had a probation provision and the outcome of successful completion of the conditions/terms of probation was to discharge and dismiss the charges, then this would be captured under "Conditional Discharge-Probation." The rationale was to be able to illustrate the concept of a conditional discharge whether or not something was strictly termed "conditional discharge," "diversion program" or the like. ${ }^{4}$

When researchers found other penalties such as probation or expungement provisions for which applicability to the lowest MJ categories of offenses was not made explicit, they were presumed to be applicable. For expungement, the inquiry was whether records of arrest, conviction, and/or other disposition could be expunged. Disincluded were the relatively rare provisions authorizing expungement only if the prosecutor decided there was insufficient evidence to justify proceeding with the charges, or the conviction was later overturned on appeal or by reason of a subsequent pardon. In such cases, even when the provision was termed expungement or expunction, the expungement variable was given a negative ascription and explanations were provided.

\footnotetext{
${ }^{4}$ Situations in which a penalty option was termed probation and successful completion did not result in discharge and dismissal were coded under "Other Penalties--Probation." Variations were captured textually in comments fields. In the few situations in which unconditional discharges were authorized, researchers were instructed to code in the affirmative under " $\mathrm{CD}$ /Div" and to note in comments fields the fact that no conditions were attached as well as the corresponding eligibility requirements and the end result, typically complete discharge and dismissal of charges and that it does not constitute a conviction. Care was taken to differentiate this permutation from other CD programs where enumerated conditions must be met.
} 


\section{Decriminalization during the 1970s}

The "Shaffer Commission," formally known as the National Commission on Marijuana and Drug Abuse, technically defined the term decriminalization in the United States in 1972. Decriminalization was defined as those policies in which possession of marijuana for personal use or casual distribution of small amounts for no remuneration was not considered a criminal offense (National Commission on Marijuana and Drug Abuse, 1972). State laws that retained the level of offense corresponding to a crime, which includes misdemeanor and felony charges, but simply lowered the severity of penalties for possession of small amounts of marijuana were not to be properly termed decriminalized.

An examination of the state statutes passed by the original eleven decriminalized states reveals that many states do not meet this narrow definition. Table 1 presents summary information on the classification of the possession offense, the amount of marijuana the law applied to, the applicability of the reduced penalties to subsequent offenses, and the maximum fine and minimum jail time specified in these eleven statutes. A number of interesting findings are evident from these original statutes. First, two of the original statutes retain marijuana possession as a criminal offense (California and North Carolina). ${ }^{5}$ We find this particularly interesting given that the policy of retaining a criminal offense contradicts the definition of decriminalization espoused by the National Commission. Second, the definitions of what constitutes a small amount of marijuana also vary significantly across these eleven state statutes. For example, Ohio defines "small” as possession of less than 100 grams (almost four ounces) while California, Maine, Mississippi, Nebraska and Oregon define small as generally an ounce or

\footnotetext{
${ }^{5}$ Both felony and misdemeanor classifications are legally criminal offenses and produce a criminal record. However, Minnesota's "petty misdemeanor" and Ohio's "minor misdemeanor" offense statuses are not classified as criminal offenses because their legal statutes clearly specify that the offense charge would not be considered a criminal offense.
} 
less. Maine, Minnesota, New York and North Carolina do not explicitly define "small" in their statutes but leave it up to the courts to decide. Third, a number of the original decriminalization states only allowed reduced penalties for first time offenders, not repeat offenders. States that only reduced penalties for first time offenders often had much harsher penalties for second time offenders, suggesting that they were not really softening their penalties against use but were instead trying to reduce some of the burden on law enforcement and the courts.

The only common denominator across these eleven statutes was the lack of imposition of minimum jail/prison terms. In some cases these reduced penalties applied to first and subsequent offenses (e.g., Alaska, California and Colorado) and in other cases the reduced penalties only applied to first time offenders (e.g., Minnesota, Mississippi and North Carolina). The common denominator of not specifying minimum jail or prison sentences for first-time possession offenders caught possessing small amounts of marijuana represents a characterization of these laws that is based on "depenalization," rather than decriminalization. The problem with such a characterization of the statutes, as will be illustrated in the next section, is that today it does not allow us to uniquely identify those states commonly viewed as decriminalized.

\section{Decriminalization today.}

If we strictly apply the definition used by the National Commission on Marihuana and Drug Abuse (1972) to each state's 1999 penalty structure, four of the so-called decriminalized states have retained first time marijuana offenses as a criminal offense (see Table 2). ${ }^{6}$ Arizona specifies first time marijuana possession offenses as a felony, while Alaska, California, and

\footnotetext{
${ }^{6}$ There are 12 states labeled as decriminalized in the 1999 data because in 1996 Arizona decriminalized marijuana possession offences in 1996 Drug Medicalization, Prevention and Control Act (Proposition 200). The act states that first and second time marijuana offenders would not be imprisoned for simple possession or use, regardless of the
} 
North Carolina specify it as a misdemeanor. Eight of the twelve decriminalized states lower the offense status to a non-criminal characterization. What is important to note, however, is that seven non-decriminalized states (Connecticut, Louisiana, Massachusetts, New Jersey, Vermont, Wisconsin, and West Virginia) also specify first time marijuana possession offenses as noncriminal offenses. Thus, reducing the criminal status of marijuana possession offenses clearly does not uniquely identify the twelve "decriminalized" states.

States can also reduce the penalties associated with an offense through conditional discharge and expungement provisions. A conditional discharge provision enables convicted offenders to choose participation in alternative diversion programs (e.g. community service, drug treatment, drug education, etc) where, if the offender successfully completed the program, s/he would be afforded the opportunity to have the original charges dismissed. With a few exceptions, the charge, however, remains part of the individual's criminal record. Some states include expungement of the offense with their conditional discharge provisions (although expungement provisions can exist outside of conditional discharge provisions as well) in essence removing the incident from the individual's criminal record, assuming that specific conditions are met (e.g., community service, probation, etc). The possible removal of the criminal charge through expungement, therefore, may be the primary method by which some decriminalized states reduce the criminality of the possession offense.

Table 3 illustrates the number of states that provide the opportunity for expungement of a criminal charge by decriminalization status and status offense. Twenty-one states (41\%) allow for expungement of the offense from the record, only four of which are decriminalized states. More importantly, two out of the four decriminalized states that have retained marijuana 
possession as a criminal offense do not allow for expungement. These findings further call into question why some states are labeled decriminalized when (a) some of those states given the label have not in fact reduced or rescinded the criminal status of these offenses, and (b) some states that are not given the label also reduce the impact of criminal status of these offenses either through changes in status offenses or through the inclusion of expungement provisions.

One possible explanation for these findings is that original differences in state policies that existed in the late 1970s became mute as non-decriminalized states changed their penalties over time, looking more like decriminalized states. Evidence from statutes in effect in late 1989 suggests that any convergence in policies that might have occurred over time happened fairly quickly (see Table 4). By December 1989, six non-decriminalized states had already lowered the status offense of marijuana possession to a non-criminal offense and another twelve nondecriminalized states had statutory conditions for expungement of the record.

Perhaps the problem is our literal interpretation of "decriminalization" and reliance on the definition provided by the National Commission. It was clear in the eleven original statutes (Table 1) that the only common denominator across these original statutes was the removal of jail time. If we use this as our alternative standard for identification of decriminalized states, or look a little more generally at monetary fines and jail time imposed across decriminalized and non-decriminalized states, we begin to see some minor differences across non-decriminalized and decriminalized states in 1989. Table 5 reveals that decriminalized states have on average lower minimum and maximum statutory jail terms specified, although only the differences in maximum jail terms are statistically significant. Apparent differences in minimum and maximum fines across decriminalized and non-decriminalized states are not statistically significant. 
When we take into account conditional discharge provisions, which enable convicted offenders to accept alternative sanctions (such as drug treatment, drug education, and/or community service) prefatory to the dismissal of charges, we find that there are very few real differences in mandatory jail time statutorily imposed across decriminalized and non decriminalized states in 1989 (see Table 6). Thirty-one of the thirty-eight non-decriminalized states that have statutory maximum jail terms greater than a day allow for conditional discharge of first time offenders. Thus, only seven states statutorily impose jail time that cannot be circumvented via diversion provisions, again reinforcing the conclusion that hypothesized differences in decriminalized versus non-decriminalized states are not statutorily based.

\section{Decriminalization: why does it matter?}

Perhaps it is not surprising, in light of the previous discussion, that the current literature examining the effect of marijuana decriminalization on marijuana use has generated such inconsistent results (see Pacula et al., 2001, for a comprehensive review). The eleven (and since 1996 twelve) states that are typically considered decriminalized do not appear to be homogenous in significant ways that enable them to be differentiable from non-decriminalized states, at least from a statutory basis. ${ }^{7}$ What variation then does this variable capture in empirical analyses conducted on data during the 1990's and how should we interpret its significance or insignificance?

In an effort to try to answer these questions, we conduct our own analysis of the effect of this policy and its principal dimensions on the use of marijuana using a nationally representative

\footnotetext{
${ }^{7}$ There may be other aspects of these policies, not captured herein, that make them differentiable from nondecriminalized states, such as the implementation of these policies, the willingness to arrest and/or prosecute offenders, and/or the symbolism of their enactment. These alternative hypotheses are discussed in greater detail later in the paper.
} 
sample of high school students from the National Educational Longitudinal Survey (NELS).

Annual and thirty-day prevalence measures of marijuana use are estimated using probit analysis, controlling for a standard set of regressors typically included in marijuana demand equations (see Pacula et al, 2001; Saffer and Chaloupka, 1999; Chaloupka et al. 1999; Thies and Register, 1993; DiNardo \& Lemieux, 1992). Systematically, different dimensions of marijuana depenalization policies (e.g. change in status offense, reduced jail time, etc) are included in the empirical specification to determine the effect these additional controls have on the findings of the marijuana decriminalization dummy variable. By building the empirical models in this manner, we can evaluate whether some of the inconsistencies in the previous literature are due to differences in how the decriminalization policy was operationalized. ${ }^{8}$ In addition, these models should provide some insight into what the decriminalized dummy variable actually represents.

Data from the first follow-up wave of the National Educational Longitudinal Survey (NELS), conducted in Spring of 1990, is being used for this analysis. The NELS is a large-scale, school-based, longitudinal study that follows a nationally representative sample of American eighth graders in 1988 as they move through the U.S. school system and into activities of early adulthood. In spring of 1988, questionnaires and subject-specific achievement tests were given to 24,599 students in more than 1,000 public and private schools in the spring of 1988 . Separate surveys were also administered to the students' parents, teachers, and school principals at this time. Follow-ups of the respondents were conducted in the spring of 1990, when most of the

\footnotetext{
${ }^{8}$ Different studies operationalized the policy of decriminalization in different ways. Some analyses include only an indicator for decriminalization (DiNardo \& Lemiux, 1992; Thies and Register, 1993), while others include measures of fines and/or jail time (Chaloupka et al, 1999; Chaloupka, Grossman and Tauras, 1999). These subtle differences can have profound effects on the interpretation of the decriminalization dummy variable in particular analyses given that the additional measures (e.g. jail time) capture key dimensions along which the general policy of decriminalization is supposed to differ. In fact, a recent study by Williams and Dolemon (2000) in which they examined the impact of different Australian depenalization regimes on consumption employing individual-level data from the 1988, 1991, 1993, 1995 and 1998 National Drug Strategy Household Surveys (NDSHS) shows that the impact of Australian decriminalization on demand is also sensitive to the inclusion of fine and incarceration data.
} 
youth were sophomores in high school, and then in 1992, when most were high school seniors. A fourth and fifth follow-up, conducted in spring of 1994 and 2000 respectively, have also been conducted documenting post-high school educational and labor market experiences of student respondents. Although the retention rate has been fairly high, refresher samples were added in the second and third follow-ups to ensure that cross sectional analyses of $10^{\text {th }}$ and $12^{\text {th }}$ graders could be conducted on nationally representative samples from these grades. The first follow-up includes responses from roughly 22,500 students, including almost 1,000 early dropouts. Only those remaining in high school $(\mathrm{n}=19,602)$ in 1990 are being included in this analysis so that findings can be easily replicated using other national school-based surveys.

Although the focus of the NELS is clearly to track educational performance, achievement and subsequent job market entry and outcomes, significant information pertinent to estimating demand equations for illicit drugs is also collected, including general demographics, socioeconomic status, religiosity, family composition and living situation, family cohesion and stressors, time spent in other activities, part-time work experience and income, and students' perceptions and attitudes. Unlike many national surveys, including the Monitoring the Future study, the NELS includes respondents from all 50 states so it is possible to maximize the variation in state level policies.

One limitation of the NELS for conducting analyses of substance use is that information on past year (past month) illicit drug use is only available in the first and second follow-up surveys. In each of these surveys, respondents were asked "How many times have you used marijuana in the past 12 months (last 30 days)?" Categorical responses provided for each of these questions were $0,1-2,3-19$, and $20+$. A dichotomous indicator signifying use in the past 
year (month) was constructed from this measure, with students indicating any positive use (greater than 0 occasions) being assigned a value of 1 .

Because marijuana use information is only available for two years, it is not possible to construct a long enough panel to identify policy effects separately from unobserved state heterogeneity. Although this is a limitation of the current analysis, most of the recent econometric studies examining the impact of decriminalization on marijuana use rely on crosssectional variation for policy identification because there has been so little variation in the decriminalization dummy variable over time. Thus, by limiting our analysis to a single crosssection of data, we make our current examination of the policy consistent with previous evaluations. However, future research should examine the extent to which findings obtained from cross-sectional variation can be attributable to real policy affects.

Table A1 in the appendix provides weighted descriptive statistics on the sample of $10^{\text {th }}$ grade students ( $1^{\text {st }}$ follow up) who were included in this analysis. Observations are lost due to missing information on various control variables (e.g. gender, ethnicity, parental education, religious attendance, income, and hours worked), although approximately 1,500 observations are lost due to missing information on marijuana use in the past year (month). Approximately $14 \%$ of the students report having used marijuana in the past year, while $7.1 \%$ report having used it in the previous 30 days. These estimates are slightly lower than those reported for $10^{\text {th }}$ graders from the Monitoring the Future (MTF) Study in 1991, the first year in which the MTF study collected data on $10^{\text {th }}$ graders. $^{9}$ Approximately $30 \%$ of the $10^{\text {th }}$ graders in our sample reside in a so-called decriminalized state in 1990. Given that the NELS is conducted in the spring of each school year, we matched statutory policy data in effect as of December 31, 1989 to the sample so 
that we can reflect laws that were in effect over the same time period consumption is being evaluated. $^{10}$

In addition to the state-level marijuana policy data discussed above, various prices have been merged into the NELS data to capture the influence of these variables on the demand for marijuana. State-level beer and cigarette taxes, obtained from Brewers' Almanac and Tobacco Institute respectively, are merged in based on the respondent's state of residence. ${ }^{11}$ Marijuana price information is obtained from various publications of the DEA Office of Intelligence or Intelligence Division, which report quarterly price data for wholesale and retail level commercial grade marijuana from nineteen regional division offices. ${ }^{12}$ Because the price data provided in these reports is sparse for some location/quarters, missing data is imputed using regression analysis on quarterly data from 1985 through 2000. The imputed annual and quarterly price series are then merged into the sample based on the proximity of the respondent's county of residence to one of the 19 division offices. A continuous measure of the distance between the respondent's school and the 19 division offices is also included to capture the quality of the match. Imputed annual price measures are used in analyses of use in the past year. Imputed quarterly prices, matched to the date of interview, are used in analyses of use in the past thirtydays.

\footnotetext{
${ }^{9}$ MTF reports annual and thirty-day prevalence rates of $16.5 \%$ and $8.7 \%$ respectively (source: http:www.monitoringthefuture.org/ data/01 data.html\#2001data-drugs). However, Alaska and Hawaii are never included in the MTF's sampling frame.

${ }^{10}$ Only two states changed their penalty structures between 1989 and 1990 and both of these took effect some time in late spring and/or early July of 1990.

${ }^{11}$ Frank Chaloupka graciously made these data available to us.

${ }^{12}$ The name of the publication including the price data has changed over time. In 1990, the publication was entitled, "Illicit Drug Wholesale/Retail Price Report." Price information for wholesale and retail level sinsemilla marijuana is also available in this report.
} 


\section{Results from the NELS}

Table 7 reports findings from various models examining the association between marijuana decriminalization and marijuana use. Each column represents a unique empirical specification of the model. Panel A of the table reports marginal effects from a series of probit models estimating the probability of using marijuana in the past year. Panel B reports similar results from identical models that estimate the probability of using marijuana in the past thirty days. All regression models include as additional regressors cigarette and beer tax, race indicators, gender, parental education, parental socio-economic composite measure, age, earned income, hours worked, high school program type, private/public schools, and religious attendance. The findings with respect to these additional controls are suppressed in an effort to conserve space, but a table of the full results from the basic model (M1) is provided in the appendix (Table A2). All regressions are weighted and standard errors are adjusted for clustering at the state level. ${ }^{13}$

Given that we are only examining one year of data, we will not be able to disentangle a true policy effect of any of these state variables from unobserved state factors that might be correlated with them, such as sentiment regarding marijuana use. Although additional years of data would be helpful for interpreting the real influence of the legal statute data, it would not help in identifying the real effect of decriminalization, our main variable of interest. This is because only two states have officially changed their status since the 1970 s, so there is insufficient variation in this policy across time. Nonetheless, by incrementally adding to the regression dimensions of the criminal status and severity of penalties associated with marijuana

\footnotetext{
${ }^{13}$ Additional models were run adjusting standard errors for clustering at the school level, but there were no significant differences in results from those presented here. Given that the focus of this paper is on the significance of state-level policy variables, we considered it most appropriate to account for intra-class correlation at this more aggregate level.
} 
use in each state, we should still expect to see the association between marijuana use and decriminalization diminish if the decriminalization variable reflects in any way a reduction in the criminality of marijuana. That is the empirical strategy employed here.

Model 1 (Column M1) simply evaluates the impact of living in a so-called decriminalized state on marijuana prevalence rates for our sample of youth. ${ }^{14}$ We find that youths living in decriminalized states are $2 \%$ more likely to use marijuana both in the past year and in the past month, although the finding with respect to annual use is not statistically significant at conventional levels. The finding of a statistically significant decriminalization effect in the past month prevalence equation differs from findings obtained by Thies and Register (1993) and Pacula (1998), who both show no statistical relationship between a marijuana decriminalization dummy variable and thirty-day prevalence of marijuana use using the National Longitudinal Survey of Youth (NLSY) . However, it is consistent with findings obtained by other researchers using data from the Monitoring the Future (MTF) Study and the National Household Survey on Drug Abuse (NHSDA) (Chaloupka et al., 1999a, 1999b Saffer and Chaloupka, 1999a and 1999b). For example, Chaloupka et al. (1999a) find that high school seniors living in decriminalized states have a 4 to $5 \%$ higher probability of marijuana use in the past year using data from the 1982 and 1989 cross-sections of the Monitoring the Future Study. Saffer and Chaloupka (1999b) also showed a 4\% increase for youth living in decriminalized states using data from the 1988, 1990 and 1991 NHSDA. ${ }^{15}$ Our current estimate presented in Column M1,

\footnotetext{
${ }^{14}$ Arizona is not included as a decriminalized state because its decriminalization policy did not take effect until 1996.

${ }^{15}$ One reason why the estimate presented in Column M1 in Table 7 is smaller than previous estimates is the inclusion of a measure of the monetary price of marijuana, which has been omitted from the previous studies mentioned. The inclusion of this variable does reduce the size of the marginal effect on the decriminalization dummy variable in some of the specifications, but not all of them. Further, the marginal effect drops by only a few percentage points so the change is not substantial.
} 
therefore, is lower than estimates obtained from the literature examining the influence of only this variable.

In light of our findings in the previous section, one has to wonder why this variable is positive and statistically significant at all. There are at least two plausible explanations that we can empirically test here. The first is that the marijuana decriminalization variable really does capture, albeit poorly, some sort of differential legal treatment of marijuana possession offenders. Although this is typically conceptualized as a reduction in the criminality of these offences, our previous descriptive results suggest that it may be more strongly associated with reductions in the penalties associated with use. We examine variations of this hypothesis in Columns M2 through M5. The second plausible explanation is that the variable is simply identifying states with relatively lower levels of enforcement of marijuana laws. We test this hypothesis in Column M6.

To examine the extent to which the decriminalization dummy variable might reflect reduced penalties associated with marijuana possession, we begin by including as additional regressors the statutorily-imposed minimum jail time and maximum fine associated with possession of any small amount (the first quantity trigger) in Column M2. ${ }^{16}$ This is a specification similar to that employed by Chaloupka et al (1999b), Chaloupka et al (1999a) and Williams et al., (2001), although the last two studies only included fines. Theoretically, the inclusion of these variables should reduce the significance of the marijuana decriminalization variable because they capture relevant domains along which decriminalization is supposed to matter across states. We find that the inclusion of these penalty variables reduces the magnitude of the decriminalization variable in both the annual and thirty-day prevalence specification by

\footnotetext{
${ }^{16}$ Alternative models were run using other combinations of $\min / \mathrm{max}$ jail and fines as well. The inclusion of alternative measures of jail time and fines does not significantly alter the finding for decriminalization status.
} 
0.2 percentage points (or approximately $10 \%$ ). However, marijuana decriminalization remains statistically significant at the $1 \%$ level in the thirty-day prevalence specification, providing empirical support for the hypothesis that the decriminalization variable is capturing something other than lower penalties.

Although maximum fines were not statistically associated with either annual or thirty-day prevalence, higher minimum jail times were statistically associated with lower prevalence rates for both measures. The marginal effect of a one-year change in minimum jail time is substantially larger than a change in decriminalization status in all of the specifications, demonstrating that marijuana use is in fact very sensitive to the statutory penalties imposed.

In the next specification of the model (Column M3) we include measures of the criminal status of marijuana possession offences, with felony status as the omitted reference group. Even if a state lowers its penalties associated with possession of small amounts of marijuana, it may still retain its status as a criminal offence (defined as either a felony or misdemeanor charge), which raises the cost of being found guilty given that it can result in the denial of certain privileges, loans, and employment opportunities. For most states, however, penalties are determined by the classification of the offence, so there is a high degree of collinearity between an offense's criminal status and the penalties imposed for that offense.

We see in Column M3 of Table 7 that lower criminal status is positively associated with increased prevalence of marijuana use both in the past year and in the past thirty days, but these results are not statistically significant. Furthermore, the inclusion of these measures does not significantly reduce the association between decriminalization and marijuana use. Given the results presented in Table 4, these regression results are not terribly surprising. They just reinforce the conclusion that the so-called decriminalized states have been misnamed and any 
policy effect obtained from this dummy variable cannot be attributed to a reduction in the criminality of marijuana use.

In Column M4 we consider the fact that many states can reduce penalties through provisions that divert first time offenders from jail and/or remove the criminal record upon successful completion of specified sanctions. To the extent that these represent a reduction in the expected penalty associated with marijuana possession offenses, we need to evaluate whether their inclusion reduces the association between decriminalization and marijuana use. We see in Column M4 that there is no statistical association between expungement and marijuana use in either the past thirty days or the past year, consistent with our findings regarding the actual criminality of the offence. Conditional discharge provisions are positively associated with marijuana use in both models, although the significance of the finding is greater in the model predicting thirty-day use. The inclusion of these two variables substantially increases the association between decriminalization and marijuana use, contrary to what we would expect if the decriminalization variable were proxying legal penalties associated with use. Furthermore, the decriminalization dummy variable is now statistically significant at conventional levels in the annual participation model.

In light of the substantial effect these two measures have on our main variable of interest, it would be useful to verify that variables have the anticipated association with marijuana use when evaluated by themselves. We therefore show in Column M5 a specification of the model that excludes marijuana decriminalization and shows the effect of just the price and statutory penalty variables. Findings from this specification suggest that there is some correlation between the decriminalization dummy variable and these two policy dimensions. The sign on the expungement variable changes from negative to positive, although it remains statistically 
insignificant. Further, there is an enormous reduction in the significance and magnitude of the coefficient on the conditional discharge variable. Other specifications, not shown here, reveal that there is significant correlation between the decriminalization and conditional discharge variables, that causes the coefficient on both of these variables to rise in magnitude and statistical significance in Column M4.

The combined findings from Columns M4 and M5 are perplexing. Conditional discharge provisions, by themselves, appear to have no additional affect on marijuana use, as indicated in Column M5 and additional analyses not reported here. This is not to say that a removal or reduction in mandated jail time does not matter, however, because higher minimum jail times are still associated with lower annual and thirty day prevalence rates in both columns. In fact, the coefficient on minimum jail time is slightly larger (in absolute value terms) in Column M5 than in Columns M2 and M4, suggesting that there may indeed be a small aspect of the marijuana decriminalization dummy variable that is associated with reduced jail time. The association is clearly small, however, because the minimum jail time variable only increases in absolute value by $9 \%$ with the exclusion of the decriminalization variable.

The fact that the coefficient on the conditional discharge variable becomes marginally significant and larger in absolute value terms when marijuana decriminalization is included in the regression suggests that the decriminalization dummy variable is picking up something that would have otherwise been left in the error term and possibly biasing the coefficient on conditional discharge downward, such as unobserved state sentiment toward marijuana use caused by cultural, political, and social factors in these states that are associated with more leniency toward marijuana use. This is further supported by the fact that the coefficient on the marijuana decriminalization dummy variable becomes larger in absolute value in both the annual 
and thirty-day prevalence equations. Thus, by including all aspects of the legal statutes that might reduce or eliminate jail sentences imposed with marijuana possession offences, and hence reduce marijuana use, the decriminalization dummy variable is left to reflect only the aspects of the policy, sentiment behind the policy, or other unobserved state-level factors that increase marijuana use. What is important to note is that these non-penalty aspects of the decriminalization dummy variable are statistically associated with marijuana use in the past year now as well, not just use in the past month.

Fundamentally, the results from Columns M1 through M5 show that the marijuana decriminalization dummy variable does not solely reflect lower statutory penalties associated with marijuana possession offences. If it did, then this variable should become statistically insignificant when these legal statutory variables were included in the model. Further, it does not reflect a change in the criminal status of the offence, confirming results from the descriptive statistics presented earlier. The evidence from the models presented in Column M4 and M5 suggest that it may be capturing unobserved state-level factors that are associated with lenient attitudes toward marijuana use, but there are other aspects of this policy implementation that remain unspecified in the model, such as enforcement, which we turn to examine now.

In Column M6 we evaluate the extent to which the decriminalization dummy variable reflects differences in the relative enforcement of marijuana possession offences. To capture differences across states in the enforcement of marijuana possession offences, we construct a ratio of state aggregated marijuana possession arrests per 10,000 residents to total arrests per 10,000 residents using county-level data from 1990 Uniform Crime Reports. ${ }^{17}$ Although this measure does not accurately reflect the risk of getting caught, which is perhaps more relevant for predicting demand and would be calculated as the ratio of marijuana possession arrests to use per 
capita, it does provide us with a measure of the extent to which law enforcement activities are focused on (or interested in) marijuana possession offenses versus other offenses. States that have higher ratios of marijuana possession arrests to total arrests per 10,000 residents can be viewed as having greater enforcement of this law. ${ }^{18}$

Although we see in Column M6 that the arrest ratio is negatively associated with both measures of marijuana use, it is not statistically significant in either model. This is consistent with what was found by Farrelly et al (1999). More importantly, however, the inclusion of this variable does not reduce the coefficient estimate on the decriminalization variable suggesting that it is not differences in the enforcement of the laws that is causing the marijuana decriminalization dummy variable to be positive and statistically significant in the previous models.

Looking across all of the specifications presented in Table 7, there are a couple of interesting things to note. First, although the decriminalization variable is consistently statistically significant in the thirty-day prevalence model, it is only statistically significant at conventional levels in the annual prevalence models when conditional discharge is also included in the model. One hypothesis is that youth who report use of marijuana in the past thirty days are more involved users and hence more likely to be aware of the policy (and whatever signal that gives). However, if this is indeed the case, then one would expect that the marijuana decriminalization variable would have a larger effect in the thirty-day prevalence equation than in the annual prevalence equation, not just be statistically more significant. In most of the models, however, the estimated coefficient on the decriminalization dummy variable in the

\footnotetext{
${ }_{17}^{17}$ Missing data in particular counties were imputed using an algorithm developed by RAND.

${ }^{18}$ An earlier analysis by Farrelly et al (1999) uses the same measure to proxy enforcement risk and finds that it is negatively and statistically associated with past month marijuana use among 21 to 30 year olds from NHSDA, but not among 12 to 20 year olds.
} 
annual prevalence model is nearly identical to that obtained for the thirty-day prevalence model. Thus, it is not entirely clear what these different findings mean. However, it does provide at least one possible explanation for some of the inconsistent findings in the literature. The significance of the decriminalization variable obviously depends on the measure of use examined as well as the inclusion of other legal sanctions in the model.

Second, it seems clear from Columns M1 through M5 that statistically significant or insignificant findings with respect to the marijuana decriminalization dummy variable should not be interpreted as evidence supporting or refuting the impact of criminalizing or depenalizing marijuana use. The models in columns M2, M4 and M5, as well as results in the literature, show that higher penalties, particularly minimum jail times, are statistically associated with reductions in annual and thirty-day prevalence of marijuana use. However, reductions in the criminal status of marijuana or the expungement of criminal charges, as shown in Models M2 and M4 and M5, do not appear to be statistically associated with marijuana use.

There are several important limitations of the empirical analysis presented here that moderate the conclusions that can be drawn from it. First, the analysis focuses on statutory penalties, which may or may not reflect the actual penalties imposed within each state. Judges may use their own discretion when determining appropriate sanctions for particular individuals, which may or may not be influenced by the statutory penalties. Thus, variation in statutory penalties may or may not reflect variation in actual penalties imposed. However, the fact that specific aspects of these statutory laws, minimum jail time in particular, are statistically significant in the direction that theory would suggest may indicate that there is at least some positive correlation between the statutory penalties and the penalties actually imposed. 
A second limitation of the current analysis is that it only examines behavior among youth. We do not know the extent to which these statutory laws apply to minors. Because of their junior status, courts may take greater leniency on juveniles committing drug possession offenses. Given that softer penalties may be imposed on minors and empirical estimates of the effects of these laws are being evaluated on a sample of youth, the coefficient estimates presented here are likely to suffer some downward bias. In addition, youth may have little knowledge of the statutory laws and/or their state's decriminalization status. This again suggests that findings presented here might understate the actual effect of these laws on demand in the general population (who presumably may have greater knowledge of the laws than the current sample being evaluated). Further, youths have higher discount rates than adults, so penalties received in the future (jail times) may have less of an impact for youths than for adults. All of these facts suggest that the findings presented here are a lower bound of the impact the real policies are likely to have on the demand for marijuana in the general population.

A final limitation is that there is some potential that the estimated association between state policy variables and marijuana use suffer from an omitted variable bias. As has been noted elsewhere, this analysis relies on cross-sectional variation in the statutory law and decriminalization policies for identification. The results from this analysis, therefore, may or may not reflect true policy effects if these state law and policy variables are statistically correlated with unobserved state factors that are not captured in the model.

\section{Discussion and Conclusions}

It is clear from the analyses presented here that "decriminalization" does not mean what researchers and policy analysts thinks it means. Several non-decriminalized states have reduced 
the criminal status of marijuana possession offenses either through changing the statutory offense or through conditional discharge and expungement provisions. An even larger number of nondecriminalized states have reduced the statutory penalties associated with marijuana possession offenses. Hence, decriminalized states are not uniquely identifiable based on statutory law as has been presumed by researchers over the past twenty years.

What is also clear from this analysis is that the policy of decriminalization appears to mean something, even if it is not an indication of reduced criminality or penalties. Exactly what it means remains unclear. The results from Column M6 in Table 7 suggest that this variable is not picking up differences in the willingness of law enforcement to enforce existing marijuana laws. Two other possible explanations exist, however. First, formal decriminalization statutes may be an indicator of a larger social acceptance of marijuana use within the state. Second, they might be an indicator of greater public knowledge (or advertisement) of the reduced penalties associated with possession of marijuana. Our data are insufficient to explore these two alternative hypotheses; future work is clearly needed.

Although it is not clear how we should interpret the findings for decriminalization, one finding that is clear from this analysis is that demand for marijuana among youth is sensitive to the penalties imposed with its use. Results presented in Table 7 suggest that a one-day increase in statutorily imposed minimum jail time is associated with a 7 to 9 percentage point reduction in annual marijuana prevalence and a 4 percentage point reduction in thirty-day prevalence. This represents a change in predicted prevalence of over $50 \%$ for both measures of use. Higher maximum fines are generally associated with reduced thirty-day prevalence of marijuana use and higher annual prevalence, but none of these results is statistically significant. This differs substantially from previous findings that have generally shown fines to be negatively and 
significantly associated with both the prevalence of marijuana use (e.g. Farrelly et al, 2001). Future work evaluating these statutory data using panel data needs to be done to evaluate the extent to which the findings reported here can be interpreted as real policy effects. 


\section{References}

Cameron L. and J. Williams. 2001. Cannabis, alcohol and cigarettes: substitutes or complements? Economic Record 77(236): 19-34.

Chaloupka, F.J., Grossman M., and J. Tauras. 1999a. "The Demand for Cocaine and Marijuana by Youth." Published in The Economic Analysis of Substance Use an Abuse: An integration of econometric and behavioral economic research. Ed. Frank Chaloupka, Michael Grossman, Warren Bickel and Henry Safer. University of Chicago Press.

Chaloupka, F.J., Pacula, R.L., Farrelly, M.C., Johnston, L., and P. O’Malley. 1999b. Do higher cigarette prices encourage youth to use marijuana? NBER Working Paper no. 6938. Cambridge, Mass.: National Bureau of Economic Research.

Chriqui, J.F., Pacula R.L., McBride D.C., Reichmann, D.A., VanderWaal, C.J., and Y. TerryMcElrath. 2002. Illicit Drug Policies: Selected Laws from the 50 States. Berrien Springs, MI: Andrews University.

DiNardo, J. and T. Lemieux. 1992. Alcohol, marijuana, and American youth: The unintended effects of government regulation. NBER Working Paper no. 4212. Cambridge, Mass.: National Bureau of Economic Research.

Farrelly M.C. Bray J.W., Zarkin, G.A., and B.W.Wendling. 2001. The joint demand for cigarettes and marijuana: Evidence from the National Household Surveys on Drug Abuse. Journal of Health Economics 20: 51-68.

Farrelly, M.C., Bray J.W., Zarkin, G.A., Wendling, B.W. and R.L. Pacula. 1999. The Effects of Prices and Policies on the Demand for Marijuana: Evidence from the National Household Surveys on Drug Abuse. NBER Working Paper No. 6940. Cambridge, Mass: National Bureau of Economic Research.

Johnston L. D., P. M. O’Malley, and J. G. Bachman. 1981. Marijuana decriminalization: The impact on youth 1975-1980. Monitoring the Future Occasional Paper no. 13. Ann Arbor, Michigan: Institute for Social Research, University of Michigan.

MacCoun, R. and P. Reuter. 2001. Drug War Heresies: Learning from Other Vices, Times and Places. New York, Cambridge University Press.

Maloff, D. 1981. A review of the effects of the decriminalization of marijuana. Contemporary Drug Problems, Fall, 307-322.

Model K. 1993. "The effect of marijuana a decriminalization on hospital emergency room episodes: 1975-1978." Journal of American Statistical Association 88 (423): 737-747.

National Commission on Marihuana and Drug Abuse. 1972. Marihuana: A Signal of Misunderstanding. First Report of the National Commission on Marihuana and Drug Abuse. Washington, D.C.: U.S. Government Printing Office, March. 
Pacula, RL. 1998. Does increasing the beer tax reduce marijuana consumption? Journal of Health Economics 17 (5): 557-586.

Pacula, R.L.; Grossman, M; Chaloupka, F.J.; P. O’Malley; L.D. Johnston and M.C. Farrelly. 2001. "Marijuana and Youth" in Jonathan Gruber's An Economic Analysis of Risky Behavior Among Youths. University of Chicago Press.

Saffer H. and F.J. Chaloupka. 1999a. The demand for illicit drugs. Economic Inquiry 37(3): 401-411.

Saffer H. and F.J. Chaloupka. 1999b. "Demographic Differentials in the Demand for Alcohol and Illicit Drugs" in The Economic Analysis of Substance Use an Abuse: An integration of econometric and behavioral economic research. Ed. Frank Chaloupka, Michael Grossman, Warren Bickel and Henry Safer. University of Chicago Press.

Single, E. 1989. The impact of marijuana decriminalization: An update. Journal of Public Health Policy, 10, 456-466.

Single, E., Christie, P. and R Ali. 2000. "The impact of cannabis decriminalisation in Australia and the United States" Journal of Public Health Policy 21(2) 157-186.

Thies, C.F., and C.A. Register. 1993. Decriminalization of marijuana and the demand for alcohol, marijuana and cocaine. Social Science Journal 30 (4): 385-399.

Williams J. 2002. The effects of price and policy on cannabis use: What can be learned from the Australian experience? University of Adelaide Working Paper.

Williams J., Pacula R.L., Chaloupka, F. and H. Wechsler. 2001. Alcohol and marijuana use among college students: Economic complements or substitutes? NBER Working Paper No. 8401. Cambridge, Mass.: National Bureau of Economic Research. 
Table 1

Summary of the Original "Decriminalization" Statutes from the 1970's

\begin{tabular}{|c|c|c|c|c|c|}
\hline $\begin{array}{l}\text { State } \\
\text { (Citation) }\end{array}$ & $\begin{array}{l}\text { Offense } \\
\text { Classification }\end{array}$ & Amount & $\begin{array}{l}\text { First } \\
\text { Offense } \\
\text { Only? }\end{array}$ & $\begin{array}{l}\text { Max } \\
\text { Fine }\end{array}$ & $\begin{array}{l}\text { Min } \\
\text { Jail }\end{array}$ \\
\hline $\begin{array}{l}\text { Alaska } \\
\text { Laws of 1975, Ch. 110; ALASKA } \\
\text { STAT. } \$ 17.12 .011 \text { (Michie 1975) }\end{array}$ & $\begin{array}{l}\text { Not specified } \\
\text { (NS) }\end{array}$ & $\begin{array}{l}\text { Any amount of MJ in } \\
\text { private place. One } \\
\text { ounce or less in a } \\
\text { public place. }\end{array}$ & No. & $\$ 100$ & NS \\
\hline $\begin{array}{l}\text { California } \\
\text { Laws of 1975, Ch. 248; } \\
\text { CAL. Health \& Safety CODE } \\
\S 11357 \text { (b) and (c) (West 1975) }\end{array}$ & Misdemeanor & One ounce & No. & $\$ 100$ & NS \\
\hline $\begin{array}{l}\text { Colorado } \\
\text { Laws of 1975, Ch. 115; } \\
\text { COLO. REV. STAT. §12-22-412 } \\
(1975)\end{array}$ & $\begin{array}{l}\text { Class } 2 \text {-petty } \\
\text { offense }\end{array}$ & One ounce or less & No. & $\$ 100$ & NS \\
\hline $\begin{array}{l}\text { Maine } \\
\text { Laws of 1975, Ch. 499; } \\
\text { ME. REV. STAT. ANN. tit. 22, § } \\
2383 \text { (1975) }\end{array}$ & Civil violation & NS. "usable amount" & No. & $\$ 200$ & NS \\
\hline $\begin{array}{l}\text { Minnesota } \\
\text { Laws of 1976, Ch. 42; } \\
\text { MINN. STAT. } § 152.15(1976)\end{array}$ & $\begin{array}{l}\text { Petty } \\
\text { misdemeanor }\end{array}$ & NS. "small amount" & Yes. & $\$ 100$ & $\mathrm{NS}$ \\
\hline $\begin{array}{l}\text { Mississippi } \\
\text { Laws of 1977, Ch. 482; } \\
\text { MISS. CODE. ANN. §41-29-139 } \\
\text { (1977) }\end{array}$ & Offense & One ounce or less & Yes. & $\$ 250$ & NS \\
\hline $\begin{array}{l}\text { Nebraska } \\
\text { Laws of 1978, Act No. 808; } \\
\text { NEB. REV. STAT. §28-416(9) } \\
(1978)\end{array}$ & Infraction & One ounce or less & Yes. & $\$ 100$ & $\mathrm{NS}$ \\
\hline $\begin{array}{l}\text { New York } \\
\text { Laws of 1977, Ch. 360; } \\
\text { N.Y. Penal Law } \$ 221.05 \\
\text { (McKinney 1977) }\end{array}$ & Violation & NS & No. & $\$ 100$ & NS \\
\hline $\begin{array}{l}\text { North Carolina } \\
\text { Laws of 1977, Ch. 862; } \\
\text { N.C. GEN. STAT. } \$ 90-95 \text { (1977) }\end{array}$ & Misdemeanor & NS & Yes. & NS & NS \\
\hline $\begin{array}{l}\text { Ohio } \\
\text { Laws of 1976, Act No. 300; } \\
\text { OHIO REV. CODE ANN. } \\
2925.11(\mathrm{C}) \& \text { (D) (1976) }\end{array}$ & $\begin{array}{l}\text { Minor } \\
\text { misdemeanor }\end{array}$ & Less than 100 grams & No. & NS & NS \\
\hline $\begin{array}{l}\text { Oregon } \\
\text { Laws of 1973, Ch.680; } \\
\text { OR. REV. STAT. } \$ 167.207(3) \\
(1973)\end{array}$ & Violation & Less than one ounce & No. & $\$ 100$ & NS \\
\hline
\end{tabular}


Table 2

State-level Decriminalization and Offense Status

For Marijuana Possession Offenses, 1999

\begin{tabular}{llc}
\hline $\begin{array}{l}\text { Decriminalization } \\
\text { Status }\end{array}$ & Offense Status & Frequency \\
\hline Yes & Felony & 1 \\
& Misdemeanor & 3 \\
& Other or not specified & 8 \\
No & Felony & 1 \\
& Misdemeanor & 31 \\
& Other or not specified & 7 \\
\hline
\end{tabular}

Table 3

State-level Offense Status and Expungement For Marijuana Possession Offenses, 1999

\begin{tabular}{llcc}
\hline $\begin{array}{l}\text { Decriminalization } \\
\text { Status }\end{array}$ & \multicolumn{1}{c}{ Offense Status } & \multicolumn{2}{c}{ Expungement } \\
\hline Yes & Felony & 0 & No \\
& Misdemeanor & 2 & 1 \\
& Other or not specified & 2 & 6 \\
No & Felony & 0 & 1 \\
& Misdemeanor & 15 & 16 \\
& Other or not specified & 2 & 5 \\
\hline
\end{tabular}

* Note: states that do not specify (or clearly permit) expungement in their statutes are included in the "No" category.

Table 4

State-level Offense Status and Expungement

For First-Time Marijuana Possession Offenses at Lowest Quantity Trigger, 1989

\begin{tabular}{llcc}
\hline $\begin{array}{l}\text { Decriminalization } \\
\text { Status }\end{array}$ & \multicolumn{1}{c}{ Offense Status } & Expungement \\
\hline Yes & Felony & 0 & No \\
& Misdemeanor & 2 & 0 \\
\multirow{2}{*}{ No } & Other or not specified & 2 & 5 \\
& Felony & 0 & 2 \\
& Misdemeanor & 12 & 19 \\
& Other or not specified & 2 & 4 \\
\hline
\end{tabular}

* Note: states that do not specify (or clearly permit) expungement in their statutes are included in the "No" category. Also note that Arizona in this table is categorized as a non-decriminalized state because its decriminalization statute did not get enacted until 1996. 
Table 5

Average Minimum and Maximum Jail Terms and Fines for Possession of Any Positive Amount ( $1^{\text {st }}$ Trigger) by State Decriminalization Status

1989

\begin{tabular}{cccc}
\hline Penalty & $\begin{array}{c}\text { Decrim States } \\
(\mathrm{n}=11)\end{array}$ & $\begin{array}{c}\text { Non-Decrim States } \\
(\mathrm{n}=\mathbf{4 0})\end{array}$ & $\begin{array}{c}\text { Significant } \\
\text { Difference? }\end{array}$ \\
\hline $\begin{array}{c}\text { Minimum jail } \\
\text { (years) }\end{array}$ & $\mathbf{0 . 0 0 0 2 7}$ & $\mathbf{. 0 5}$ & No \\
$\begin{array}{c}\text { Maximum jail } \\
\text { (years) }\end{array}$ & $\mathbf{. 0 0 3}$ & $\mathbf{. 7 6 9 4}$ & Yes (1\% level) \\
Minimum fine & $\$ 72.73$ & & No \\
Maximum fine & $\mathbf{\$ 2 4 0 . 9 1}$ & $\mathbf{\$ 3 0 . 0 0}$ & No \\
\hline
\end{tabular}

Table 6

State-Level Decriminalization Status, Maximum Jail Time and Conditional Discharge Marijuana Possession Offenses for Any Positive Amount $\left(1^{\text {st }}\right.$ Trigger, 1989

\begin{tabular}{|c|c|c|c|}
\hline \multirow[t]{2}{*}{$\begin{array}{l}\text { Decriminalization } \\
\text { Status }\end{array}$} & \multirow[t]{2}{*}{ Maximum Jail } & \multicolumn{2}{|c|}{$\begin{array}{c}\text { Conditional } \\
\text { Discharge/Diversion }\end{array}$} \\
\hline & & Yes & No \\
\hline \multirow[t]{2}{*}{ Yes } & Not specified & 3 & 7 \\
\hline & 0.03 years & 1 & 0 \\
\hline \multirow[t]{11}{*}{ No } & 0 & 2 & 0 \\
\hline & 0.003 years & 1 & 0 \\
\hline & 0.04 years & 1 & 0 \\
\hline & 0.08 years & 1 & 0 \\
\hline & 0.082 years & 5 & 0 \\
\hline & 0.25 years & 1 & 0 \\
\hline & 0.493 years & 1 & 0 \\
\hline & 0.5 years & 6 & 2 \\
\hline & 1 year & 13 & 5 \\
\hline & 1.5 years & 1 & 0 \\
\hline & 6.0 years & 1 & 0 \\
\hline
\end{tabular}


Table 7

NELS 10th Grade Sample, 1990

Marginal Effects From Probit Estimation of Likelihood of Using Marijuana

Findings for Marijuana Penalty Variables Only

\begin{tabular}{|c|c|c|c|c|c|c|}
\hline & \multicolumn{5}{|c|}{ Panel A: $\operatorname{Pr}$ (Marijuana Use in the Past Year) } & \multirow[b]{2}{*}{ M6 } \\
\hline & M1 & M2 & M3 & M4 & M5 & \\
\hline \multirow[t]{2}{*}{ Decriminalized state } & $0.017^{\mathrm{d}}$ & 0.015 & $0.018^{d}$ & $0.026^{\mathrm{b}}$ & & $0.029^{b}$ \\
\hline & $(0.012)$ & $(0.012)$ & $(0.012)$ & $(0.014)$ & & $(0.014)$ \\
\hline \multirow[t]{2}{*}{ Geometric Mean Price of MJ } & $-1.50 \mathrm{E}-03^{\mathrm{c}}$ & $-1.60 \mathrm{E}-03^{b}$ & $-1.35 \mathrm{E}-03^{c}$ & $-1.55 E-03^{b}$ & $-1.58 \mathrm{E}-03^{\mathrm{C}}$ & $-1.65 \mathrm{E}-03^{b}$ \\
\hline & $(0.001)$ & $(0.001)$ & $(0.001)$ & $(0.001)$ & $(0.001)$ & $(0.001)$ \\
\hline \multirow[t]{2}{*}{ Maximum Fine } & & $1.23 \mathrm{E}-07$ & & 9.35E-08 & $8.81 \mathrm{E}-08$ & $6.48 \mathrm{E}-08$ \\
\hline & & $(1.27 E-07)$ & & $(1.26 \mathrm{E}-07)$ & $(1.33 E-07)$ & $(1.44 \mathrm{E}-07)$ \\
\hline \multirow[t]{2}{*}{ Minimum Jail } & & $-0.072^{a}$ & & $-0.074^{a}$ & $-0.081^{a}$ & $-0.090^{a}$ \\
\hline & & $(0.012)$ & & $(0.013)$ & $(0.012)$ & $(0.020)$ \\
\hline \multirow[t]{2}{*}{ Misdemeanor } & & & 0.012 & & & \\
\hline & & & $(0.031)$ & & & \\
\hline \multirow[t]{2}{*}{ Non-Criminal Offence } & & & 0.005 & & & \\
\hline & & & $(0.036)$ & & & \\
\hline \multirow[t]{2}{*}{ Expungement } & & & & -0.004 & 0.007 & -0.009 \\
\hline & & & & $(0.013)$ & $(0.012)$ & $(0.013)$ \\
\hline \multirow[t]{2}{*}{ Conditional Discharge } & & & & $0.019^{d}$ & 0.005 & $0.023^{c}$ \\
\hline & & & & $(0.012)$ & $(0.012)$ & $(0.013)$ \\
\hline \multirow[t]{2}{*}{ MJ poss arrest/ Total arrests } & & & & & & -0.376 \\
\hline & & & & & & $(1.151)$ \\
\hline Number of Observations & 13,383 & 13,383 & 13,383 & 13,383 & 13,383 & 12,469 \\
\hline Pseudo-R2 & 0.060 & 0.065 & 0.064 & 0.065 & 0.065 & 0.067 \\
\hline Observed Probability & 0.142 & 0.142 & 0.142 & 0.142 & 0.142 & 0.142 \\
\hline \multirow[t]{3}{*}{ Predicted Probability } & 0.126 & 0.126 & 0.126 & 0.126 & 0.126 & 0.125 \\
\hline & & anel B: $\operatorname{Pr}(M$ & ana Use in th & ist Month) & & \\
\hline & M1 & M2 & M3 & M4 & M5 & M6 \\
\hline \multirow[t]{2}{*}{ Decriminalized state } & $0.018^{a}$ & $0.016^{a}$ & $0.017^{\mathrm{a}}$ & $0.028^{a}$ & & $0.028^{a}$ \\
\hline & $(0.006)$ & $(0.006)$ & $(0.007)$ & $(0.011)$ & & $(0.011)$ \\
\hline \multirow[t]{2}{*}{ Geometric Mean Price of MJ } & $-2.87 \mathrm{E}-04^{b}$ & $-3.04 \mathrm{E}-04^{b}$ & $-2.92 \mathrm{E}-04^{b}$ & $-2.72 \mathrm{E}-04^{\mathrm{C}}$ & $-2.69 E-04^{d}$ & $-2.16 \mathrm{E}-04$ \\
\hline & $(1.45 E-04)$ & (1.47E-04) & $(1.49 E-04)$ & $(1.48 \mathrm{E}-04)$ & $(1.78 \mathrm{E}-04)$ & (1.67E-04) \\
\hline \multirow[t]{2}{*}{ Maximum Fine } & & $-5.84 \mathrm{E}-08$ & & $-8.47 \mathrm{E}-08$ & $-9.28 \mathrm{E}-08^{d}$ & $-7.16 \mathrm{E}-08$ \\
\hline & & $(5.38 E-08)$ & & (5.53E-08) & (6.08E-08) & (6.82E-08) \\
\hline \multirow[t]{2}{*}{ Minimum Jail } & & $-0.043^{a}$ & & $-0.042^{a}$ & $-0.049^{a}$ & $-0.042^{a}$ \\
\hline & & $(0.009)$ & & $(0.008)$ & $(0.011)$ & $(0.013)$ \\
\hline \multirow[t]{2}{*}{ Misdemeanor } & & & $0.015^{d}$ & & & \\
\hline & & & $(0.010)$ & & & \\
\hline \multirow[t]{2}{*}{ Non-Criminal Offence } & & & 0.018 & & & \\
\hline & & & $(0.014)$ & & & \\
\hline \multirow[t]{2}{*}{ Expungement } & & & & -0.010 & 0.001 & -0.011 \\
\hline & & & & $(0.008)$ & $(0.008)$ & $(0.009)$ \\
\hline \multirow[t]{2}{*}{ Conditional Discharge } & & & & $0.016^{c}$ & $6.86 \mathrm{E}-05$ & $0.015^{c}$ \\
\hline & & & & $(0.008)$ & $(0.007)$ & $(0.009)$ \\
\hline \multirow[t]{2}{*}{ MJ poss arrest/ Total arrests } & & & & & & -0.341 \\
\hline & & & & & & $(0.686)$ \\
\hline Number of Observations & 13,818 & 13,818 & 13,818 & 13,818 & 13,818 & 12,468 \\
\hline Psuedo-R2 & 0.075 & 0.075 & 0.075 & 0.076 & 0.074 & 0.074 \\
\hline Observed Probability & 0.076 & 0.076 & 0.076 & 0.076 & 0.076 & 0.075 \\
\hline Predicted Probability & 0.061 & 0.061 & 0.061 & 0.061 & 0.061 & 0.061 \\
\hline
\end{tabular}

Notes: (1) All probit regressions include as additional regressors the following variables: cigarette tax, beer tax, race indicators (black, hispanic, asian, other), gender, parental education, parental socio-economic composite measure, age, earned income, hours worked, high school program type, private/public schools, and religious attendance. (2) All probit regressions are weighted and adjusted for clustering at the state level. (3) Superscripted letters indicate the following: "a" indicates significance at the $1 \%$ level (two-tailed test), "b" indicates significance at 5\% level (two-tailed test), "c" indicates significance at 10\% level (two-tailed test), and " $d$ " indicates significance at the 10\% level (one-tailed test). 


\begin{tabular}{|c|c|c|c|c|c|}
\hline \multirow[b]{2}{*}{ Variable } & \multicolumn{5}{|c|}{$\begin{array}{c}\text { Appendix } \\
\text { Table A1 } \\
\text { Descriptive Statistics for } 1990 \text { 10th Grade Sample from NELS }\end{array}$} \\
\hline & & Mean & Std. Dev. & Min & Max \\
\hline \multirow[t]{2}{*}{ MJ use } & Use in the past year & 0.139 & 0.346 & 0 & 1 \\
\hline & Use in the past month & 0.071 & 0.257 & 0 & . \\
\hline Demographics & Hispanic & 0.109 & 0.311 & 0 & 1 \\
\hline \& Background & African American & 0.084 & 0.277 & 0 & 1 \\
\hline \multirow[t]{16}{*}{ Variables } & White, Non-Hispanic & 0.737 & 0.440 & 0 & 1 \\
\hline & American Indian, Alaskan native & 0.009 & 0.098 & 0 & 1 \\
\hline & Asian, Pacific Islander (omitted category) & & & & \\
\hline & Female & 0.520 & 0.500 & 0 & 1 \\
\hline & Age & 17.034 & 0.795 & 15 & 19 \\
\hline & Highest parent ed $=$ HS grad & 0.189 & 0.392 & 0 & 1 \\
\hline & Highest parent ed $=$ some college & 0.392 & 0.488 & 0 & 1 \\
\hline & Highest parent ed = college graduate & 0.335 & 0.472 & 0 & 1 \\
\hline & Parental SES in 2nd Quartile & 0.230 & 0.420 & 0 & 1 \\
\hline & Parental SES in 3rd Quartile & 0.242 & 0.429 & 0 & 1 \\
\hline & Parental SES in 4th Quartile & 0.329 & 0.470 & 0 & 1 \\
\hline & Occasional religious attendance & 0.177 & 0.382 & 0 & 1 \\
\hline & Infrequent/never religious attendance & 0.392 & 0.488 & 0 & 1 \\
\hline & Frequent religious attendance (omitted category) & & & & \\
\hline & Income from work & 55.999 & 71.411 & 0 & 600 \\
\hline & Hours worked & 1.301 & 1.436 & 0 & 5 \\
\hline School & HS program - College prep/academic & 0.375 & 0.484 & 0 & 1 \\
\hline \multirow[t]{11}{*}{ Characteristics } & HS program- Vocationa/technical & 0.079 & 0.270 & 0 & 1 \\
\hline & HS program - Other specialized high & 0.051 & 0.220 & 0 & 1 \\
\hline & HS program - Special Ed program & 0.065 & 0.247 & 0 & 1 \\
\hline & HS program -Alternative / Drop out & 0.017 & 0.130 & 0 & 1 \\
\hline & HS program - regular (omitted category) & & & & \\
\hline & Suburban & 0.396 & 0.489 & 0 & 1 \\
\hline & Rural & 0.324 & 0.468 & 0 & 1 \\
\hline & Urban (omitted category) & & & & \\
\hline & Catholic School & 0.059 & 0.236 & 0 & 1 \\
\hline & Other private school & 0.080 & 0.271 & 0 & 1 \\
\hline & Public school (omitted category) & & & & \\
\hline \multirow[t]{5}{*}{ Prices } & Real annual mean price of oz MJ (1982-1984 dollars) & 76.64 & 22.498 & 33.13 & 135.22 \\
\hline & Real quarterly mean price of oz MJ (1982-1984 dollars) & 92.689 & 18.782 & 59.40 & 127.96 \\
\hline & Distance btwn 19 city \& R's school (miles) & 159.734 & 144.582 & 1 & 2350 \\
\hline & Real state and fed cig tax (1982-1983 dollars) & 21.687 & 8.670 & 2 & 38 \\
\hline & Real state beer tax (1982-1983 dollars) & 0.487 & 0.507 & 0.045 & 2.37 \\
\hline MJ penalty & Decriminalization dummy & 0.301 & 0.459 & 0 & 1 \\
\hline \multirow[t]{7}{*}{ variables } & Misdemeanor Offense & 0.741 & 0.438 & 0 & 1 \\
\hline & Non-criminal offense & 0.242 & 0.429 & 0 & 1 \\
\hline & Maximum fine & 2342.830 & 14762.560 & 0 & 150000 \\
\hline & Minimum jail time & 0.019 & 0.136 & 0 & 1 \\
\hline & Expungement provision & 0.287 & 0.452 & 0 & 1 \\
\hline & Conditional discharge provision & 0.731 & 0.443 & 0 & 1 \\
\hline & Probability of arrest (MJ poss arrest / total arrests) & 0.019 & 0.006 & 0.004 & 0.045 \\
\hline
\end{tabular}


Table A2

Full Model (M1)

Marginal Effects from Probit Analysis

\begin{tabular}{|c|c|c|c|c|c|}
\hline \multicolumn{3}{|c|}{ Pr (Use in Past Year >0) } & \multicolumn{3}{|c|}{ Pr (Use in Past Month > 0) } \\
\hline Variable & $\mathrm{dF} / \mathrm{dX}$ & Std Err & Variable & $\mathrm{dF} / \mathrm{dX}$ & Std Err \\
\hline Decriminalized state & 0.017 & 0.012 & Decriminalized state & 0.018 & $0.006^{a}$ \\
\hline Annual avg real price MJ & -0.001 & $0.001^{c}$ & IQuarterly real price of MJ & $-2.94 \mathrm{E}-04$ & $1.43 \mathrm{E}-04^{\mathrm{b}}$ \\
\hline Distance of DEA match & $-7.23 E-05$ & $3.86 \mathrm{E}-05^{c}$ & Distance of DEA match & $-4.03 E-05$ & $2.56 \mathrm{E}-05^{d}$ \\
\hline Cigarette Tax 1990 & $-9.22 E-05$ & 0.001 & Cigarette Tax 1990 & $-1.11 \mathrm{E}-04$ & 0.000 \\
\hline Beer Tax 1990 & 0.018 & $0.008^{b}$ & Beer Tax 1990 & 0.010 & 0.008 \\
\hline Hispanic & 0.059 & $0.036^{c}$ & Hispanic & 0.045 & $0.029^{c}$ \\
\hline African American & -0.015 & 0.038 & IAfrican American & -0.013 & 0.019 \\
\hline White & 0.060 & $0.026^{b}$ & White & 0.039 & $0.016^{b}$ \\
\hline Other race & 0.023 & 0.052 & Other race & 0.033 & 0.037 \\
\hline Female & 0.003 & 0.009 & jFemale & -0.003 & 0.006 \\
\hline Age & 0.007 & 0.005 & Age & 0.005 & 0.004 \\
\hline Income & 3.53E-04 & $1.03 \mathrm{E}-04^{\mathrm{a}}$ & Income & $2.29 \mathrm{E}-04$ & $5.67 \mathrm{E}-05^{\mathrm{a}}$ \\
\hline Hours worked & 0.002 & 0.004 & Hours worked & -0.003 & 0.003 \\
\hline Occasional religious attendance & 0.085 & $0.016^{\mathrm{a}}$ & Occasional religious attendance & 0.038 & $0.012^{a}$ \\
\hline Infrequent/never religious attendance & 0.120 & $0.015^{a}$ & |'Infrequent/never religious attendance & 0.069 & $0.008^{a}$ \\
\hline Parent HS grad & -0.004 & 0.028 & Parent HS grad & -0.023 & 0.017 \\
\hline Parent some college & 0.006 & 0.022 & IParent some college & -0.010 & 0.019 \\
\hline Parent college grad & -0.011 & 0.024 & Parent college grad & -0.017 & 0.017 \\
\hline Parental SES 2nd Quartile & -0.017 & 0.016 & Parental SES 2nd Quartile & -0.004 & 0.007 \\
\hline Parental SES 3rd Quartile & -0.012 & 0.014 & IParental SES 3rd Quartile & 0.004 & 0.008 \\
\hline Parental SES 4th Quartile & -0.010 & 0.018 & :Parental SES 4th Quartile & 3.86E-04 & 0.010 \\
\hline HS program college prep & -0.053 & $0.008^{a}$ & THS program college prep & -0.041 & $0.005^{a}$ \\
\hline HS program vocational & -0.026 & $0.013^{c}$ & HS program vocational & -0.019 & $0.008^{b}$ \\
\hline Other HS program & -0.004 & 0.017 & Other HS program & 0.006 & 0.015 \\
\hline Don't know HS program & 0.025 & 0.021 & |Don't know HS program & 0.002 & 0.010 \\
\hline Missing HS program & -0.032 & 0.024 & 'Missing HS program & -0.001 & 0.019 \\
\hline Suburban & -0.014 & 0.011 & Suburban & -0.013 & $0.007^{c}$ \\
\hline Rural & -0.032 & $0.015^{b}$ & Rural & -0.016 & 0.010 \\
\hline Catholic school & -0.020 & 0.023 & Catholic school & -0.023 & $0.012^{c}$ \\
\hline Other private school & -0.052 & $0.024^{b}$ & IOther private school & -0.038 & $0.008^{a}$ \\
\hline Obs Probability & 0.142 & & Obs Probability & 0.074 & \\
\hline Predicted Probability & 0.126 & & :Predicted Probability & 0.060 & \\
\hline
\end{tabular}

